\title{
Characterization of Recombinant Bean Yellow Mosaic Virus belongs to Group-IV Infecting Gladiolus
}

\author{
P. Hemachandra Reddy ${ }^{1,2}$, V. Venkataravanappa ${ }^{3}$, P. Swarnalatha ${ }^{1}$, \\ K. V. Ashwathappa ${ }^{1}$ and M. Krishna Reddy ${ }^{\text {* }}$ \\ ${ }^{1}$ Division of Plant Pathology, Indian Institute of Horticultural Research (IIHR), \\ Bangalore, India \\ ${ }^{2}$ Department of Biotechnology, Centre for Post-Graduate Studies, Jain University, \\ Bangalore, India \\ ${ }^{3}$ Division of Plant Pathology, Central Horticultural Experiment Station, Chettali, India \\ *Corresponding author
}

\section{A B S T R A C T}

\section{Keywords}

Bean yellow mosaic virus,

Gladiolus,Phylogen etic analysis, RTPCR and

Recombination.

Article Info

Accepted:

18 August 2019

Available Online:

10 September 2019
Gladiolus is an important vegetatively propagated ornamental plant cultivated in different parts of the world. The major constrains for production quality and quantity of flowers in gladiolus is due to infection of different viruses. During survey, the gladiolus plants (Ten samples) with mosaic symptoms were collected from different farmer fields in Bangalore rural district and were confirmed for Bean yellow mosaic virus (BYMV) infection by ELISA and PCR using specific primers. Further compete genome of BYMV that infects gladiolus was amplified cloned and sequenced. The analysis showed that the genome of BYMV shared maximum nucleotide identity 92-97.2\% with BYMV isolates belonging to the group IV infecting different crops in India, Japan, USA and Taiwan. Further recombination analysis showed that most part of the genome was derived from BYMV isolates from the phylogenic group of IV and I to emerge as a new variant of BYMV infecting gladiolus. The significance of these findings is discussed.

\section{Introduction}

The genus Gladiolus belongs to the family Iridaceae. It consists of more then 150 species originated from Africa, Asia, South Europe and few from Mediterranean area. The cultivars of gladiolus exhibit more diversity in shape, size, flower colour, time, bulbing and dormancy (Kaur et al., 2015). Gladiolus is an important ornamental plant grown 
commercially for different purposes in worldwide. The major constrains for production of quality and quantity of flowers and corms are viruses, which are causing extensive crop yield losses.

The most conspicuous viral disease symptoms observed on the infected gladiolus plantings are stunting, flower color breaking, distortion and reduced cormel production. On the leaves severe mosaic appearance and stunted growth of the plants are common. Gladiolus is natural host for many viruses (Arneodo et al., 2005). The important viruses documented in different parts of the world are Arabis mosaic virus (ArMV), Bean yellow mosaic virus (BYMV), Broad bean wilt virus (BBWV), Cucumber mosaic virus (CMV), Soybean mosaic virus (SMV), Strawberry latent ring spot virus (SLRSV), Tobacco mosaic virus (TMV), Tobacco rings pot virus (TRSV), Tomato black ring virus (ToBRV), Tomato ringspot virus (ToRSV), Tobacco rattle virus (TRV), Tomato spotted wilt virus (TSWV), Tobacco streak virus (TSV) (Katoch et al., 2003;Dubey et al., 2010). These viruses are spread by vegetative propagation and by insect vectors.

The genus BYMV is a member of the Potyvirus (Shukla et al., 1994) infecting different leguminous and ornamental crop plants (Sasaya et al., 1998; Sutic et al., 1999). BYMV is made up of $750 \mathrm{\eta m}$ long flexuous particles, induces cylindrical inclusions bodies in host cells, and is transmitted by aphids in a non persistent manner (Edwardsons \& Christie 1986; Milne 1988).

BYMV can be readily detected in the infected gladiolus plants (Zettler \& Abo el-nil 1977) by ELISA or RT-PCR but cannot be readily detected in corm tissue (Vunsh et al., 1991). The detection ofvirus in gladiolus corms is difficult (Katoch et al., 2003) due low titer of the virus in the corms or cormlets. Limited work has been carried in India on virus morphology and serological detection of BYMV (Srivastava et al., 1983): CMV (Raj et al., 2002, Singh, et al., 2007).

Considering the above fact with high disease incidence of BYMV on gladiolus, the characterization and identification of recombinant BYMV infecting gladiolus was conducted with a long term goal to contain the disease in gladiolus.

\section{Materials and Methods}

\section{Collection of Gladiolus virus infected samples}

The roving survey was conducted for collection of symptomatic (Mosaic like symptoms on leaves and sepals, colour breaking in flowers) and asymptomatic gladiolus samples from commercially cultivated famer's fields in Bangalore rural areas and also experimental plots at ICARIndian Institute of Horticultural Research, Bangalore India. Total 10 fields were surveyed; from each field 2 samples (ten symptomatic and ten asymptomatic samples) were collected and used for analysis. Symptomatic and asymptomatic leaf samples collected were used for transmission and characterization and the remaining samples was stored at $-80^{\circ}$ for further studies.

\section{Culture maintenance}

The field collected symptomatic (Mosaic like symptoms on leaves and sepals, color breaking in flowers) gladiolus plants were initially screened with DAC-ELISA using polyclonal antibodies of Bean yellow mosaic virus (BYMV).

The virus positive gladiolus plants samples were mechanically transmitted to Beans cv. Anup by sap inoculation and maintained under insect proof glass house for further use. 


\section{Mechanical transmission}

The methodology of inoculation involved maceration of $1.0 \mathrm{~g}$ of symptomatic leaf tissue of gladiolus in $10 \mathrm{ml}$ of ice cold $0.05 \mathrm{M}$ potassium phosphate buffer $(\mathrm{pH} 7.5)$ using a sterile pestle and mortar on ice. The crushed sap was filtered through double layered muslin cloth and filtrate was mixed with celite powder (600mesh at $0.025 \mathrm{~g}$ per $\mathrm{ml}$ ). Then sap was used for mechanical inoculation on the leaves of Beans cv. Anup. The inoculated plants were kept under insect proof glass for symptoms expression. The development of local and systemic symptoms was recorded on host plants for a period of 30 days after inoculation. After that the infected young leaves were harvested and analyzed for presence of virus using DAS-ELISA and RTPCR.

\section{Partial Purification and Electron Microscopy}

The virus was partially purified from infected gladiolus sample showing mosaic symptoms collected from experimental plot at Indian institute of Horticultural Institute according to the methodology described by Kaur et al.,(2015). The partially purified virus particles were transferred to carbon coated copper grid and the excess buffer on grid was washed with $10 \mathrm{mM}$ phosphate buffer $(\mathrm{pH}$ 7.0) followed by sterile water and negativestain with $2 \%$ uranyl acetate. The morphology of partially purified virus particles was visualized in JEOL 100s electron microscope at $80 \mathrm{kv}$.

\section{Viral cDNA synthesis, PCR amplification and cloning}

Total genomic RNAs was extracted from infected gladiolus samples and plants maintained at Plant Virology Laboratory, ICAR-Indian Institute of Horticultural
Research, Bangalore, by RNeasy Plant Mini Kit (Qiagen), following the manufacturers protocol. The integrity and quality of the total RNA were checked on $1 \%$ agarose gel and also quantified by nanodrop (Thermo Fisher Scientific, USA).

The First strand viral cDNA synthesis was carried out with $5 \mu \mathrm{g}$ total RNA that was denatured along with $1.0 \mu \mathrm{l}$ reverse primer $(20 \mathrm{pmol} / \mu \mathrm{l})$ at $72^{0} \mathrm{C}$ for $5 \mathrm{~min}$, followed by addition of $4 \mu 1$ of $5 X$ first strand buffer, $0.2 \mu 1$ ribonuclease inhibitor $(40 \mathrm{U} / \mu \mathrm{l}), 2 \mu \mathrm{l}$ of $10 \mathrm{mM}$ dNTPs and $01 \mu 1$ MMLV-RT (200 $\mathrm{U} / \mu 1)$ (Fermentas) in a total reaction of $25 \mu \mathrm{l}$. Reaction was performed at $42^{\circ} \mathrm{C}$ for $60 \mathrm{~min}$ followed by incubation at $75^{\circ} \mathrm{C}$ for $5 \mathrm{~min}$.

PCR amplification was performed using sets of reverse and forward primers designed to amplify complete genome of the BYMV. PCR reactions were carried out in a GeneAmp PCR system 9700 (PE Applied Biosystems, Foster City, CA) thermocycler. PCR reactions were carried out in a volume of $25 \mu \mathrm{L}$ containing 100ng of DNA template $0.5 \mathrm{U}$ Taq DNA polymerase (Fermentas, Germany), 25mM $\mathrm{MgCl}_{2}$ (Fermentas, Germany), 2 mMdNTPs (Fermentas, Germany) and 25 pmol of each primer. The thermo cycler was set for 35 cycles of denaturation at $94^{\circ} \mathrm{C}$ for $1 \mathrm{~min}$, annealing at $58^{\circ} \mathrm{C}$ to $62^{\circ} \mathrm{C}$ for 45 seconds and extension at $72^{\circ} \mathrm{C}$ for 90 seconds with final extension at $72^{\circ} \mathrm{C}$ for $20 \mathrm{~min}$. PCR products were electrophoresed on $0.8 \%$ agarose gels stained with ethidium bromide $(10 \mathrm{mg} / \mathrm{mL})$ and were viewed in a gel documentation system (Alpha Innotech, USA).

The amplified PCR products of different genome fragments of BYMV were purified from agarose gels following standard protocols and ligated into $\mathrm{pTZ57R/T}$ vector using InsTAclone PCR product cloning kit (Fermentas, city Germany) according to the manufactures instructions. The ligated product was transformed into Escherichia coli DH5a 
competent cells (Invitro gen Bioservices India Pvt. Ltd., Bengaluru, India). Bacterial colonies bearing recombinant plasmids carrying apparent monomeric full length viral inserts of three clones from sample were selected for sequencing by automated DNA sequencer ABI PRISM 3730 (Applied Biosystems) at from Medauxin Sequencing Services, Bangalore, Karnataka, India.

\section{Sequence Analysis}

The sequence similarity searches were performed by comparing the full length genome sequence of BYMV to all available sequences in GenBank using BLASTn (Altschulet al., 1990). The Genbanksequence showing highest scores with the present isolate were obtained from database (Table 1) and aligned using SEAVIEW program (Galtier et al., 1996). The open reading frames (ORFs) located in the genome and their putative proteins were analyzed by ORF Finder (www.ncbi.nlm.nih.gov/projects/gorf/) and ExPasy translation tools (http://www.expasy. org/resources/ search/keywords: translation), respectively. The sequence identity matrixes for the BYMV infecting gladiolus were generated using Bioedit Sequence Alignment Editor (version 5.0.9) (Hall, 1999) and phylogenetic tree was generated by MEGA 7 software (Kumar et al., 2016) using the neighbor joining method with 1000 bootstrapped replications. The evidence for recombination in BYMV infecting gladiolus were analyzed by Splits-Tree version 4.3 using the neighbor-Net method (Huson and Bryant, 2006) by the alignment of selected BYMV and other potyviruses sequences. The method depicts the conflicting phylogenetic signals caused by recombination as cycles within the untreated bifurcating tree. Further recombination analysis was carried using Recombination detection program (RDP), to detect recombination in the BYMV genome with default RDP settings (Martin et al., 2015).

\section{Results and Discussion}

\section{Symptomatology and Viral Incidence}

During survey it was observed that naturally BYMV infected gladiolus plants in farmers field showed symptoms viz; mild to severe mosaic patterns on leaves, stem, and inflorescence; color breaking in floret petals and reduction of number of corms (Fig I). Apart from this, in the infected plants it was observed that the plant height, number of tillers perplant, length of spike and florets per plant were also reduced. The incidence of disease varied from field to field and recoded on the basis of visual symptoms of infected plants over healthy plants by crossing the rows of the plants. The disease incidence in gladiolus field varied from 26.8 to $80 \%$ in years 2014 to 2017 .

\section{Virus transmission}

The inoculated beans (cv. Anup) plants using crude sap obtained from infected leaf tissue of diseased gladiolus plants (showing severe mosaic symptoms) induced necrotic local lesions on leaves at 25-30 days post inoculation (dpi) (Fig II). Further the sap also induced systemic mosaic symptoms on healthy gladiolus plantlets (obtained from Division of Ornamental and Medicinal Crops ICAR-IIHR-Bangalore) at 25-30 dpi which were similar to those of naturally infected gladiolus collected from fields. The infection confirmed for presence of virus using DASELISA and RT-PCR.

\section{Virus particle morphology and Transmission Electron Microscopy}

The numerous flexuous rod particles of virus measured about $720 \mathrm{~nm} \times 11 \mathrm{~nm}$ was observed in partially purified and negatively stained preparation (Fig III). The size and shape of the virus particles observed TEM was similar 
other reported potyviruses so far (Katoch et al., 2002).

\section{Detection of BYMV infecting gladiolus and corms}

Total genomic RNA isolated from the naturally infected ten gladiolus samples was confirmed BYMV infection through PCR using potyvirus degenerate primer pairs. The resulted PCR amplicon of $\sim 1.2 \mathrm{~kb}$ was obtained in ten infected gladiolus samples. The partial amplified genome $(1.2 \mathrm{~kb})$ of BYMV was cloned and sequenced. The sequence data obtained had 99-100\% nucleotide identity with each other and 8992\% with other BYMV isolates reported worldwide. Based sequence data the isolates was identified isolate of BYMV from gladiolus. Therefore one BYMV isolate was selected (OV65) for complete genome characterization (Fauquet et al., 2005) using degenerate primer pairs (Table 1) from the infected gladiolus plant.

Molecular characterization of BYMV by complete genome sequence analysis

The complete genome of BYMV infecting gladiolus was amplified by PCR using eight primer pairs, which are overlapping four region of the viral genome (Fig IV). The expected size amplicons of $\sim 1.2 \mathrm{~kb}$ in size were obtained in all pairs of primers from infected gladiolus plants. The PCR amplified different overlapping fragments were cloned sequenced and assemble using different bioinformatics programs and the complete genome sequence data were submitted to GenBank under the accession: MK131270.

\section{Complete BYMV genome sequence analysis}

The complete genome sequence of BYMV obtained in the present study was compared with 39 BYMV isolates infecting different crops and other potyvirus obtained from GenBank. The result showed that the BYMV isolate, isolated from the infected gladiolus plant showed highest nucleotide identity ranged from 92-97.2\% with BYMV isolates (CK-GL2, G1, GDD, CKGL5, GB2, MB4, Lisianthus, Gla, MBGP, Vfaba2) infecting different crops and belonged to the group IV reported from India, Japan, USA and Taiwan (Table 2).The BYMV isolate infecting gladiolus also sheared 92.5 to $92.5 \%$ nucleotide identity with BYMV isolates (M11, Ib) infecting different crops that belonged to the group III reported from Japan. Further BYMV isolate sheared 86.8 to $87.1 \%$ sequence similarity with BYMV isolates (AR87C, ES55C, MD7, SW9, SW3.2 and LMBNN) infecting different crops of belong the group II reported from Australia. Similarly BYMV isolate sheared 86.6 to $86.7 \%$ nucleotide identity with group I BYMV isolates (SP1, PN83A, GB17A, Fr, PN80A, KP2, KP2, NG1) infecting different crops reported from Australia. The BYMV isolate showed less than $85 \%$ sequence similarity with BYMV isolates (921, S, LP, LPexFB, 902, FB, WLMV, CS) infecting different crops that belonged to different groups viz; V, VI, VII, VIII and IX respectively (Table 2). The alignment analysis of deduced amino acid residues of various proteins translated within the long polypeptide of BYMV isolate showed similar variable sequence identity with individual proteins to other phylogenetic groups (Data not shown).

\section{phylogenetic analysis}

The phylogenetic analysis was done using complete genome of BYMV isolate infecting gladiolus under study with the selected thirty nine BYMV isolates along with other potyviruses, macluravirus and ipomovirus sequences (Fig. V). 
Table.1 List of eight degenerative primer pairs used in current study

\begin{tabular}{|c|c|c|}
\hline S. No. & Primer Name & Sequence $\left(5^{\prime}-3^{\prime}\right)$ \\
\hline 1 & $\begin{array}{l}\text { BYMF20 } \\
\text { BYMR1282 }\end{array}$ & $\begin{array}{l}\text { 5' CAAGACAAYACAAGACAWAACG 3', } \\
\text { 5' GAACACRCTTGCATTRTYAAATC 3' }\end{array}$ \\
\hline 2 & $\begin{array}{l}\text { BYMF1147 } \\
\text { BYMR2326 }\end{array}$ & $\begin{array}{l}\text { 5' GTGGDTCAGTCATGGCKCTKT 3' } \\
\text { 5' CAACYCTATAAWAMTTCAGTTCAG 3' }\end{array}$ \\
\hline 3 & $\begin{array}{l}\text { BYMF2302 } \\
\text { BYMR3596 }\end{array}$ & $\begin{array}{l}\text { 5' GCAGTYCTTGACTCATATGGTTC 3' } \\
\text { 5, CACAATCRCTCCTYTCAGCATC 3' }\end{array}$ \\
\hline 4 & $\begin{array}{l}\text { BYMF3495 } \\
\text { BYMR4610 }\end{array}$ & $\begin{array}{l}\text { 5' CGAGTAACAGCAYTGRTACTCATG 3' } \\
\text { 5' CAAATCTARYTCTGGYACCAC 3' }\end{array}$ \\
\hline 5 & $\begin{array}{l}\text { BYMF4557 } \\
\text { BYMR5754 }\end{array}$ & $\begin{array}{l}\text { 5' ATGGTGTAACGCTTGACATTGAAG 3', } \\
\text { 5' GTACCTYTMACYTTTCCYETCTTTG 3', }\end{array}$ \\
\hline 6 & $\begin{array}{l}\text { BYMF5612 } \\
\text { BYMR6862 }\end{array}$ & $\begin{array}{l}\text { 5' ATTGCAGCGGGAGTGCTCGG 3' } \\
\text { 5, CAAYTTCCARCCACAACACCAG 3, }\end{array}$ \\
\hline 7 & $\begin{array}{l}\text { BYMF6769 } \\
\text { BYMR7948 }\end{array}$ & $\begin{array}{l}\text { 5' CAGGTGAYCTYAATGTGTTCAC 3', } \\
\text { 5, CATGAGYGTGTTRTCAACCACTG 3, }\end{array}$ \\
\hline 8 & $\begin{array}{l}\text { M4TR } \\
\text { WEICNF }\end{array}$ & $\begin{array}{l}\text { 5' CCAGTGGCTCTTTTTTTTTTTTTTTT 3, } \\
\text { 5' TGCTCYATHCTMAAYCGMACNAG 3' }\end{array}$ \\
\hline
\end{tabular}

Table.2 Pair wise sequence similarity (\%) of complete genome of BYMV infecting Gladiolus sp. and with other potyviruses reported in worldwide

\begin{tabular}{|c|c|c|c|c|c|c|}
\hline Viruses & Acc. number & Host species & Isolate & Place & Group & $\begin{array}{c}\text { Identity } \\
(\%)\end{array}$ \\
\hline BYMV & HG970851 & L. angustifolius & SP1: & Australia & I & 86.6 \\
\hline BYMV & HG970860 & L. angustifolius & PN83A & Australia & I & 86.6 \\
\hline BYMV & HG970852 & L. angustifolius & GB17A & Australia & I & 86.7 \\
\hline BYMV & FJ492961 & Freesia sp. & Fr & S.Korea & I & 86.5 \\
\hline BYMV & HG970861 & Freesia sp. & PN80A & Australia & I & 86.6 \\
\hline BYMV & JX173278 & D. magnifica & KP2 & Australia & I & 86.4 \\
\hline BYMV & HG970865 & L. angustifolius & KP2 & Australia & I & 86.6 \\
\hline BYMV & HG970869 & L. angustifolius & NG1 & Australia & I & 86.6 \\
\hline BYMV & HG970863 & L. angustifolius & AR87C & Australia & II & 86.8 \\
\hline BYMV & HG970858 & L. angustifolius & ES55C & Australia & II & 86.7 \\
\hline BYMV & HG970850 & Lupinus cosentinii & MD7 & Australia & II & 86.9 \\
\hline BYMV & KF632713 & Diuris sp & SW9 & Australia & - & 86.9 \\
\hline BYMV & JX156423 & Diuris sp. & SW3.2 & Australia & II & 87.1 \\
\hline BYMV & HG970855 & L. angustifolius & LMBNN & Australia & II & 87.0 \\
\hline BYMV & AB079886 & L. pilosus & M11 & Japan & III & 92.5 \\
\hline BYMV & AB079887 & G. hybrida & $\mathrm{Ib}$ & Japan & III & 92.3 \\
\hline BYMV & KM114059 & Gladiolus sp. & CK-GL2 & India & IV & 94.1 \\
\hline BYMV & AB439730 & G. hybrida & G1 & Japan & IV & 97.2 \\
\hline BYMV & AY192568 & Gladiolus sp. & GDD & USA & IV & 96.9 \\
\hline BYMV & KF155420 & Gladiolus sp. & CKGL5 & India & - & 95.5 \\
\hline BYMV & AB079888 & - & GB2 & Japan & IV & 94.7 \\
\hline BYMV & NC003492 & - & MB4 & Japan & IV & 96.8 \\
\hline
\end{tabular}




\begin{tabular}{|c|c|c|c|c|c|c|}
\hline BYMV & AM884180 & E. russellianum & Lisianthus & Taiwan & IV & 96.0 \\
\hline BYMV & AB439729 & G. hybrida & Gla & Japan & IV & 92.0 \\
\hline BYMV & D83749 & - & MBGP & Japan & IV & 96.8 \\
\hline BYMV & JN692500 & V.faba & Vfaba2 & India & IV & 93.9 \\
\hline BYMV & KT934334 & sunflower & BYSun & Iran & - & 85.4 \\
\hline BYMV & KF155419 & gladiolus & CK-GL4 & India & - & 94.0 \\
\hline BYMV & KF155414 & gladiolus & CK-GL3 & India & - & 96.8 \\
\hline BYMV & KF155409 & gladiolus & CK-GL1 & India & - & 94.4 \\
\hline BYMV & MG600297 & Trifolium pratense & PV2 & Czech Republic & - & 72.0 \\
\hline BYMV & AB439732 & Trifolium pratense & 921 & Japan & V & 84.3 \\
\hline BYMV & U47033 & V.faba & S & Australia & V & 85.5 \\
\hline BYMV & HG970866 & L. pilosus & LP & Australia & VI & 82.2 \\
\hline BYMV & HG970868 & V.faba & LPexFB & Australia & VI & 81.2 \\
\hline BYMV & AB439731 & V.faba & 902 & Japan & VII & 80.2 \\
\hline BYMV & HG970867 & V.faba & FB & Australia & VII & 79.7 \\
\hline WLMV & DQ641248 & L. albus & WLMV & USA & VIII & 78.1 \\
\hline BYMV & AB373203 & Pisum sativum & CS & Japan & IX & 75.5 \\
\hline CYVV & NC_003536 & Phaseolus vulgaris & CYVV & Japan & - & 65.4 \\
\hline CYVV & HG970870 & T. repens & CYVV & Australia & - & 64.4 \\
\hline OrMV & NC_019409 & - & OrMV & Australia & - & 52.4 \\
\hline CYNMV & NC_018455 & D. opposita & - & - & - & 39.9 \\
\hline SVYV & NC_010521 & Watermelon & - & USA & - & 42.8 \\
\hline
\end{tabular}

$\mathrm{BYMV}=$ Bean yellow mosaic virus, $\mathrm{CYVV}=$ Clover yellow mosaic virus, WLMV=White lupin mosaic virus, OrMV=Ornithogalum mosaic virus, SVYV=Squash vein yellowing virus and CYNMV=Chinese yam necrotic mosaic virus.

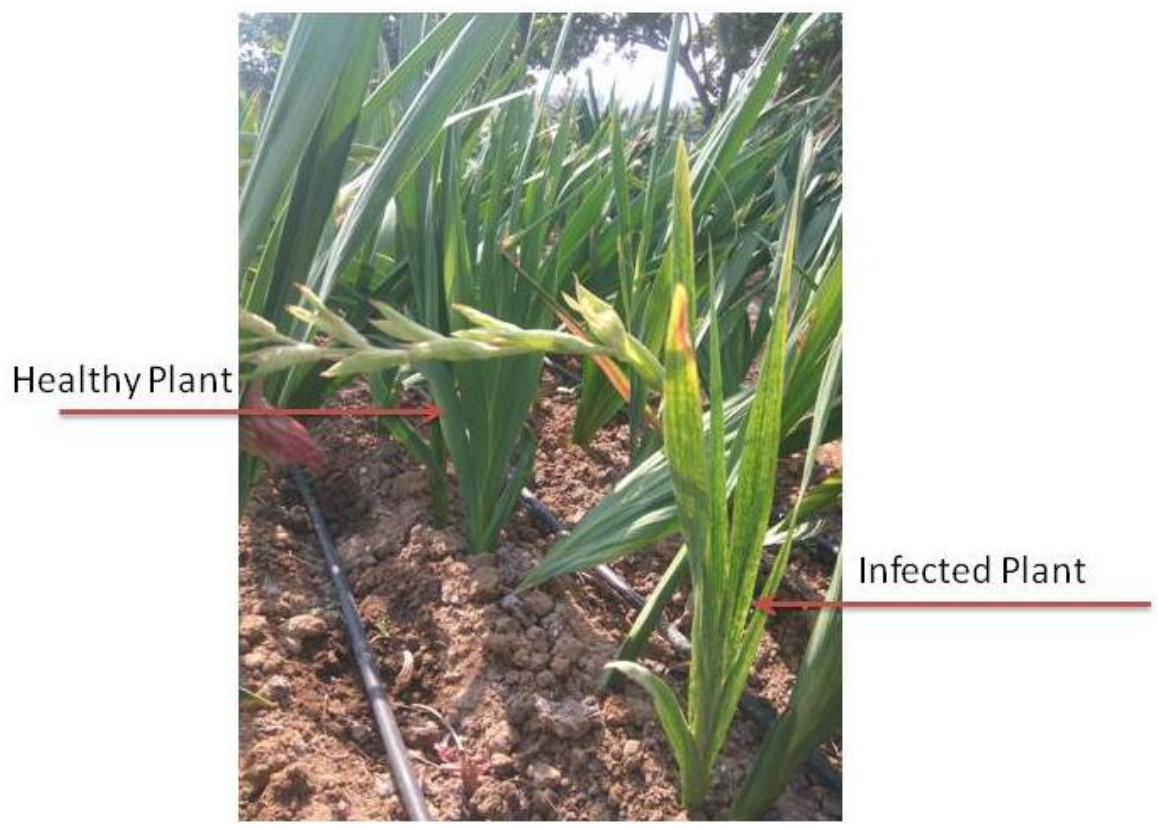

Figure.1 Symptoms of BYMV in gladiolus 
Table.3 Breakpoint analysis of BYMV infecting gladiolus and their putative parental sequences

\begin{tabular}{|c|c|c|c|c|c|c|c|c|c|}
\hline \multirow[t]{2}{*}{ BYMV } & \multirow{2}{*}{$\begin{array}{l}\text { Break } \\
\text { point } \\
\text { begin-end }\end{array}$} & \multirow[t]{2}{*}{ Major Parent } & \multirow[t]{2}{*}{ Minor parent } & \multicolumn{6}{|c|}{ P-Values } \\
\hline & & & & RDP & $\begin{array}{c}\text { GENECO } \\
\mathbf{V}\end{array}$ & Max Chi & $\begin{array}{c}\text { Chimer } \\
\text { a }\end{array}$ & Si Scan & 3Seq \\
\hline RNA & $\begin{array}{l}16-3123 \\
46-3242 \\
3977-8417 \\
6500-6624 \\
6625-8519\end{array}$ & $\begin{array}{l}\text { BYMV-KP2:Australia[I]- } \\
\text { HG970865 } \\
\text { BYMV- } \\
\text { Fr:S.Korea[I]FJ492961 } \\
\text { BYMV-S:Australia[V]- } \\
\text { U47033 } \\
\text { BYMV- } \\
\text { Fr:S.Korea[I]FJ492961 } \\
\text { BYMV-Vfaba2:India[IV)]- } \\
\text { JN692500 }\end{array}$ & $\begin{array}{l}\text { BYMV-India[IV]- } \\
\text { KF155414 } \\
\text { BYMV-India[IV]- } \\
\text { KF155414 } \\
\text { BYMV-India[IV]- } \\
\text { KT934334 } \\
\text { BYMV-India[IV]- } \\
\text { KT934334 } \\
\text { BYMV- } \\
\text { Fr:S.Korea[I]FJ492961 }\end{array}$ & $\begin{array}{c}1.777 \times 10^{-17} \\
1.73 \times 10^{-26} \\
5.509 \times 10^{-40} \\
9.423 \times 10^{-7} \\
1.360 \times 10^{-38}\end{array}$ & $\begin{array}{c}2.049 \times 10^{-17} \\
1.445 \times 10^{-24} \\
4.472 \times 10^{-26} \\
1.208 \times 10^{-4} \\
1.290 \times 10^{-26}\end{array}$ & $\begin{array}{l}1.307 \times 10^{-} \\
6 \\
4.940 \times 10^{-} \\
21 \\
3.335 \times 10^{-} \\
\frac{10}{4.479 \times 10^{-}} \\
2 \\
5.25 \times 10^{-16}\end{array}$ & $\begin{array}{c}2.605 \times 10 \\
-5 \\
2.057 \times 1 \\
0-57 \\
6.603 \times 10 \\
-11 \\
2.369 \times 10 \\
-2 \\
1.423 \times 10 \\
-16\end{array}$ & $\begin{array}{c}4.2 \times 10^{-45} \\
- \\
1.165 \times 10 \\
-38 \\
- \\
1.493 \times 10 \\
-35\end{array}$ & $\begin{array}{c}7.401 \times 10 \\
-13 \\
1.2286 \times 1 \\
0 \\
0.72 \\
2.501 \times 10 \\
-12 \\
5.755 \times 10 \\
-5 \\
1.470 \times 10 \\
-12\end{array}$ \\
\hline
\end{tabular}

NS- Recombination Non-significance 


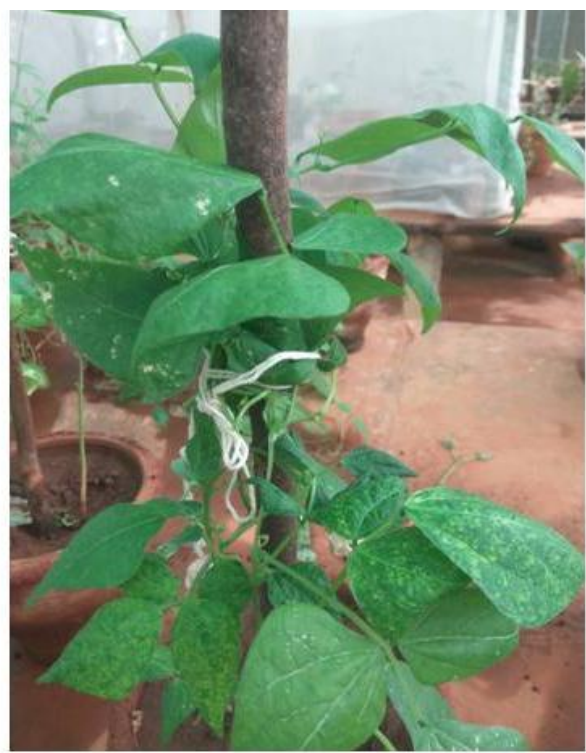

Figure II: Sap transmission of BYMV on beans

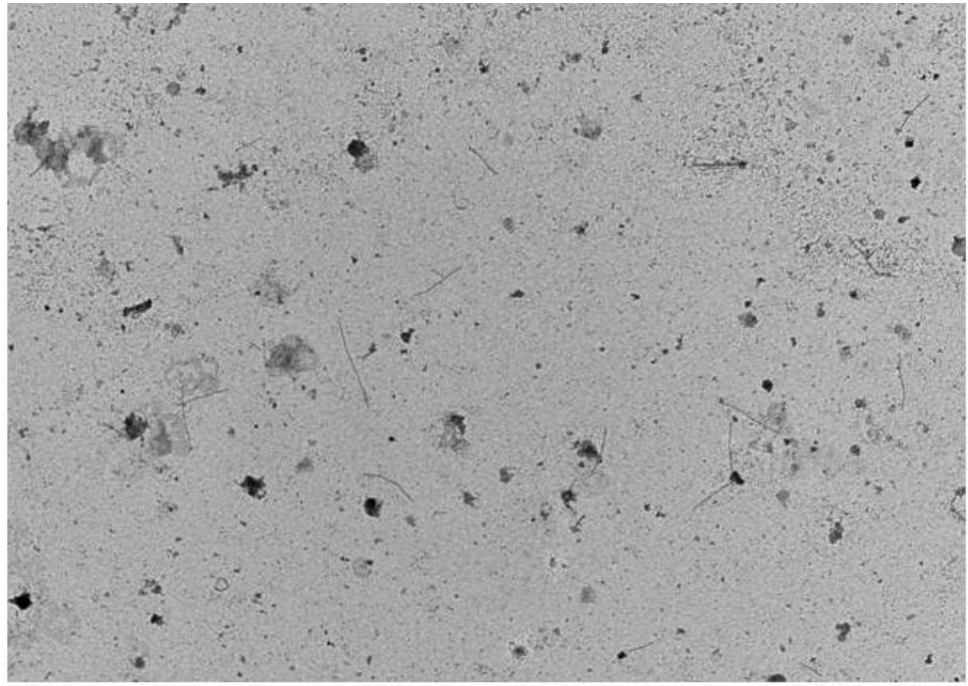

Figure III: TEM showing BYMV virus particles

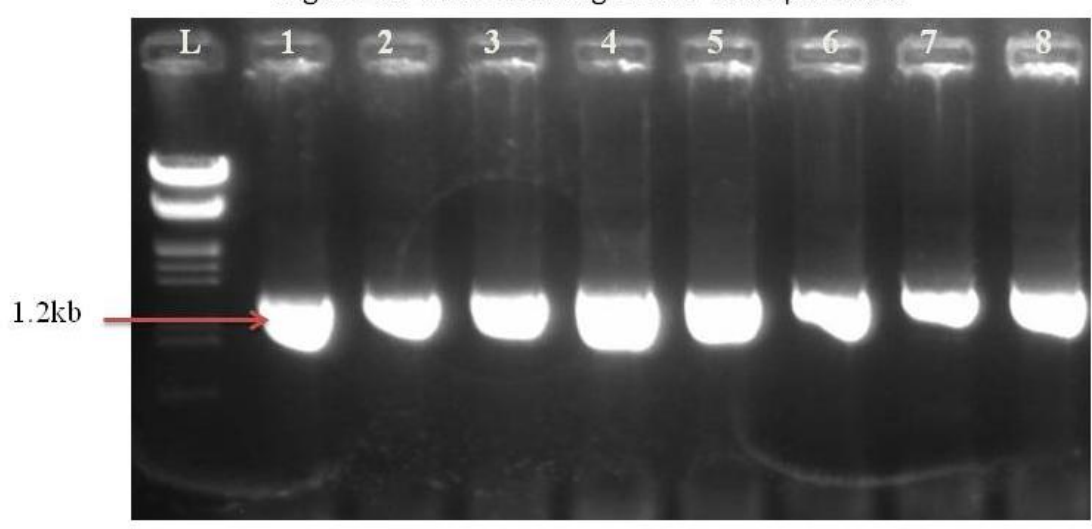

Figure IV: Amplification of full genome of BYMV using eight sets of overlapping primers (L-Ladder (EcoRI+HindIII marker), 1-8 primer sets). 


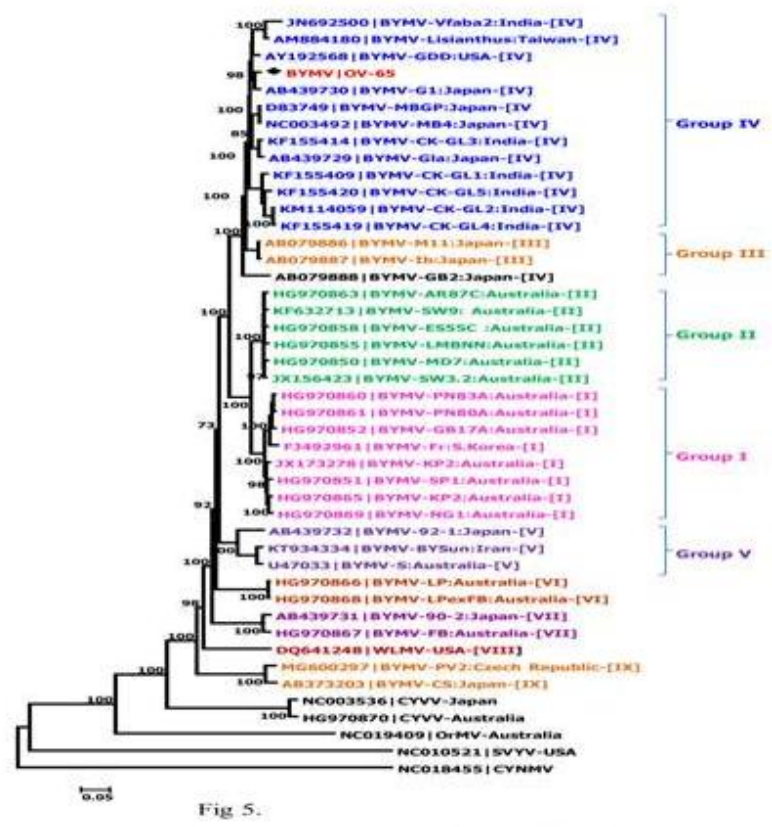

Figure V: The phylogenetic analysis of gladiolus BYMV with the selected thirty nine BYMV isolates

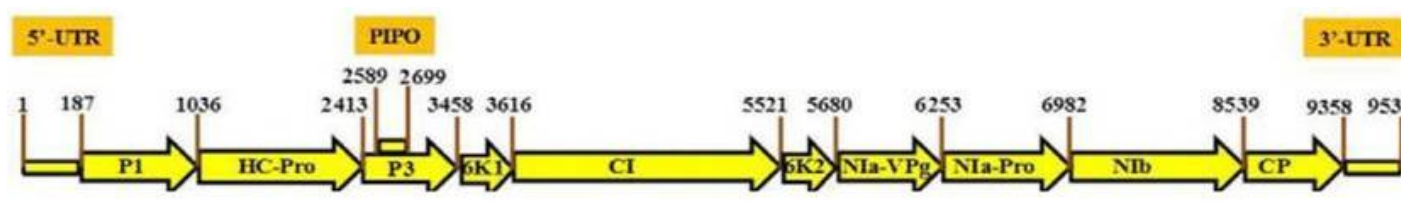
BYMV|0V65

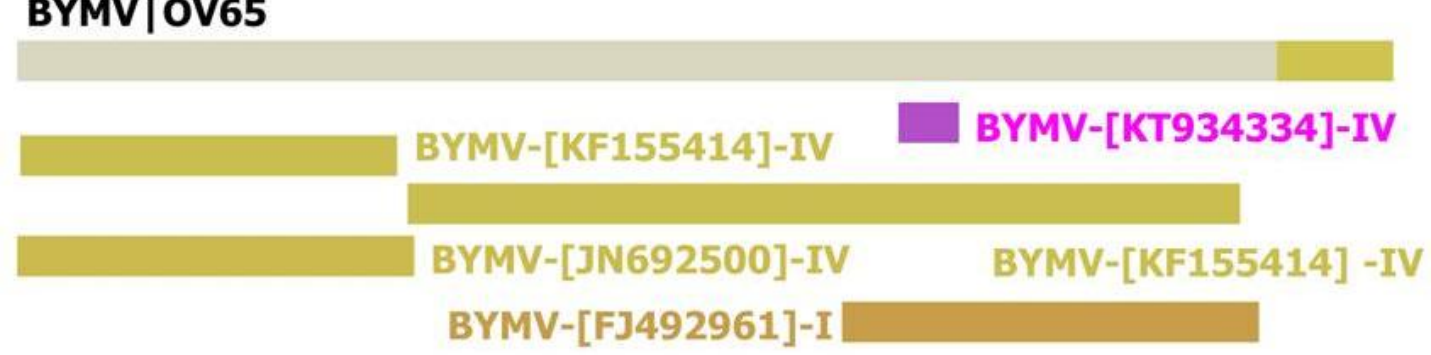

Figure VI: Neighbor-network of gladiolus BYMV using the Splits-Tree program

The complete genome of BYMV isolate infecting gladiolus is closely clustered with group IV of BYMV isolates (CK-GL2, G1, GDD, CKGL5, GB2, MB4, Lisianthus, Gla, MBGP, Vfaba2) infecting different crops reported from India, Japan, USA and Taiwan respectively. Other BYMV isolates (Australia, Japan, South Korea and USA) reported from different parts of world clustered in I-IX different phylogenetic groups, the other two closely related CYVV isolates grouped in a separate cluster, while OrMV (NC019409), 
macluravirus (NC018455) and ipomovirus (NC010521) were taken as out group. Pairwise sequence similarity and phylogenetic relationship analysis showed that the BYMV isolate infecting gladiolus in South India was closely related potyvirus isolates belonging to group IV.

\section{Neighbor-net and Recombination analysis}

A neighbor-network (using the program Splits-Tree version 4.11.3) was constructed using the sequences of different thirty nine BYMV isolates (I - IX groups) along with other potyviruses, macluravirus and ipomovirus sequences obtained from NCBI database along with the sequence of the BYMV isolate characterized in the present study. The analysis showed a reticulated network like structure indicative of phylogenetic incongruence suggesting parts of the sequences have different origins due to recombination (data not shown). The pairwise homoplasy index PHI test also strongly supported the presence of recombination BYMV isolate characterized in the present study $(\mathrm{P}<0.001)$. Further recombination break point analysis done using RDP4, indicated the evidence of intra and interrecombination group recombination in the BYMV genome infecting gladiolus and its most of the genome is derived from BYMV isolates from the phylogenic group of IV and I to emerge as a new variant of BYMV infecting gladiolus(Fig VI, Table 3). The recombination was detected with parental phylogenetic groups: IV and I. Most of the recombination was observed within the 5'UTR, a large ORF, P1 proteinase; helper component proteinase (HC-Pro); P3N-PIPO; $\mathrm{P} 3$ protein; 6K1 protein; cylindrical inclusion (CI) protein; 6K2 protein; nuclear inclusion a (NIa) protein and viral protein genome linked (VPg); the NIa proteinase (NIa-Pro); nuclear inclusion $b$ (NIb) protein; viral RNA dependent RNA polymerase and coat protein
(CP) and no recombination was detected in the 3'-UTR, of BYMV isolate (Table 3). The overall recombination analysis showed that the genome BYMV infecting gladiolus is derived from phylogenetic groups of IV and I of BYMV infecting different crops reported from India, Japan, USA, Taiwan and Australia(Table 3).

Gladiolus is an important ornamental crop grown commercially in different parts of the world. The major constrain for cultivation and production quality flowers in gladiolus are viruses, which are harbor in the propagated (corm lets) materials leads to causes significant crop yield loss (Kamo et al., 2005). Gladiolus is also natural host of many RNA viruses (AMV, BYMV, BBWV, CMV, INSPV, OrMV, SLRSV, TRV, TMV, TAV, TRSV and TSWV) belonging to diverse groups reported from different parts of the world (Raj et al., 2002\& 2011;Dorrigiv et al., 2013; Duraisamy et al., 2011; Katoch et al., 2003a\& 2003b, 2004; Kaur et al., 2011). In the present study the infected gladiolus samples and corms was collected different places of Bangalore rural areas are confirmed BYMV infection through PCR. Further to know the phylogenetic group of BYMV isolate infecting gladiolus, complete genome was characterized using different degenerative overlapping primers. Complete genome analysis of BYVMV isolate infecting gladiolus showed more homology with BYMV isolates (CK-GL2, G1, GDD, CKGL5, GB2, MB4, Lisianthus, Gla, MBGP, Vfaba2) infecting different crops of belong the phylogenetic group IV reported from India, Japan, USA and Taiwan. The genome of BYMV isolate had a length of 9532 nucleotides as depicted by the sequence excluding the poly (A) tract and similar to other BYMV isolates from different crops (Selvarajan et al., 1998). An analysis of the RNA depicts an open reading frame (ORF) having 9171 nucleotides that encode a large 
polypeptide that has 3056 amino acids, which has an average $\mathrm{mR}$ of 347,571 (Duraisamy et al., 2011). There are nine putative proteolytic cleavage sites, where one of them is cleavage by $\mathrm{P} 1$ protease, one by the $\mathrm{HC}$ protease, while the remaining seven are cleavage by the Nla protease. The genetic organization of BYMV genome has been found out from the results to be 5'UTR/CP-3'UTR (Selvarajan et al., 1998). A comparison of the amino acid sequences of each of the BYV proteins with the corresponding proteins of other potyviruses showed that the BYMV had a higher homology except the P1.

Based on the CP gene sequence analysis of different BYMV isolates, nine phylogentic groups (I to IX) of BYMV infecting different crops have been proposed so far (Kehoe et al., 2014; Wylie et al., 2008). All the isolates have broad host range infecting monocots and dicot plants. In the present our isolates also showed more sequence homology with BYMV isolates infecting mainly gladiolushybrida reported from Japan and recently proposed as BYMV phylogenetic group- IV (Kehoe et al., 2014). The result clearly showed that, introduction of BYMV with infected gladiolus plant material from different locations in different time beings this might be one of the reasons that the isolates from different locations clustered together.

Recombination is one of the key factors for rapid evolution and adaptation of RNA viruses (Gray et al., 2010) has been well documented in potyviruses in different parts other world (Gray et al., 2010, Revers et al., 1996). Recombination is found to play a major role in creating the genetic variability in the vial genome as well as increase it host range (Wylie and Jones, 2009). The recombination analysis revealed that most part of the genome is derived from BYMV isolates with intra recombination with different group (VI and I) BYMV isolates infecting different crops.
The commercial cultivation of gladiolus by most of the growers depends on the corms and corm lets. The occurrence of the mosaic disease on gladiolus gives an alarming signal against utilization of such virus infected planting materials in the crop breeding and improvement program. The technique developed here will be highly useful to detect the virus infection in clonally propagated plants such as gladiolus.

\section{Acknowledgments}

The research was supported by the project "Consortium platform on Vaccines and diagnostics" funded by Indian Council of Agricultural Research, Government of India, New Delhi, India.

\section{Competing interests}

The authors declare that they have no competing interests.

\section{References}

Altschul, S.F., Gish, W., Miller, W., Myers, E.W. and Lipman, D.J. 1990. Basic local alignment search tool. Journal of Molecular Biology. 215: 403-410.

Arneodo, J.D., S. de Breuil., Lenardon, S.L., Conci, V.C., Conci, L.R., Detection of Bean yellow mosaic virus and Cucumber mosaic virus infecting gladiolus in Argentina. 2005. Vol. XXII (2). P. 8789.

Dorrigiv, R., Jafarpour, B and Rastegar, M.F.

2013. Detection of some virus pathogens of gladiolus in Iran. Int J Agri Crop Sci. 5: 1653-58.

Dubey, V.K., Aminuddin A, Singh VP (2010) Molecular characterization of Cucumber mosaic virus infecting gladiolus, revealing its phylogeny distinct from the Indian isolate and alike the Fny strain of CMV. Virus Genes. 2010 - 41(1): 126- 
134.

Duraisamy, G.S., Pokorný, R and Holková, L. 2011. Possibility of Bean yellow mosaic virus detection in Gladiolus plants by different methods. J Plant Dis Prot. 118: 2-6.

Edwardsons, J.R., and Christie, R.G. 1986. Viruses infecting forage legumes. Vol 2, Chap 14. Monograph 14. University of Florida, Gainesville, 724 pp.

Fauquet CM, Mayo CM, Maniloff J, Desselberger U, Ball LA, 2005. Virus Taxonomy. Eighth Report of the International Committee on Taxonomy of Viruses. San Diego, CA, USA: Elsevier Academic Press, 819-29.

Galtier, N., Gouy, M and Gautier, C. 1996. SEA VIEW and PHYLO WIN: two graphic tools for sequence alignment and molecular phylogeny. Computer Applications in the Biosciences. 12: 543548.

Gray, S.M., DeBoer, S.H., Lorenzen, J., Karasev, A.V and Whitworth, J. et al., 2010. A significant and evolving threat to potato crops in the United states and Canada. Plant Dis. 94: 1384-1397.

Hall, T.A. 1999. BioEdit: a user-friendly biological sequence alignment editor and analysis program for Windows 95/98/NT. Nucleic Acids. 41: 95-98.

Huson, D.H and Bryant, D. 2006. Application of phylogenetic networks in evolutionary studies. Molecular Biology and Evolution. 23: 254-267.

Kamo, K., Gera, A., Cohen, J., Hammond, J., and Blowers, A. et al., 2005. Transgenic Gladiolus plants transformed with the bean yellow mosaic virus coat-protein gene in either sense or antisense orientation. Plant Cell Rep. 23: 654-663.

Katoch, M., Ram, R., Zaidi, A.A and Garg, I.D. 2002. Status of bean yellow mosaic virus on Gladiolus. Crop Prot. 21: 86165.

Katoch, M., Abdin, M.Z., Ram, R and Zaidi,
A.A. 2003a. An overview of diagnostics for viruses infecting gladiolus. Crop Prot. 22: 153-56.

Katoch, M., Abdin, M.Z and Zaidi, A.A. 2004. First report of Tobacco rattle virus occurring in gladiolus in India. Plant Pathol. 53: 236.

Katoch, M., Ram, R and Zaidi, A.A. 2003b. First report of Tobacco ringspot virus occurring in gladiolus in India. Plant Pathol. 52:789.

Katoch, M., Abdin, M.Z., Ram R and Zaidi, A.A. An overview of diagnostics for viruses infecting gladiolus // Crop Protection. 2003. N. 22.P. 153-156.

Kaur, C., Kumar, S., Raj, S.K., Chauhan, P.S and Sharma, N. 2015. Characterization of a new isolate of Bean yellow mosaic virus Group-IV Associated with Mosaic disease of Gladiolus in India. J Plant Pathol Microb. 6: 309. Doi: 10.4172/2157- 7471.1000309.

Kaur, C., Raj, S.K., Snehi, S.K., Goel, A.K and Roy, R.K. 2011. Natural occurrence of Ornithogalum mosaic virus newly reported on gladiolus in India. New Dis Rep. 24, 2.

Kehoe, M.A., Coutts, B.A., Buirchell, B.J and Jones, R.A. 2014. Plant virology and next generation sequencing: experiences with a Potyvirus. PLoS One. 9: e104580.

Martin, D.P., Murrell, B., Golden, M., Khoosal, A and Muhire, B. 2015. RDP4: Detection and analysis of recombination patterns in virus genomes. Virus Evolution, Vol 1, Issue 1, vev003.

Milne, R.G. 1988. The filamentous plant viruses. In: The plant viruses. Plenum Press, New York. 423 pp.

Raj, S.K., Kumar, S., Verma, D.K and Snehi, S.K. 2011. First report on molecular detection and identification of Tomato aspermy virus naturally occurring on gladiolus in India. Phytoparasitica 39: 303-307.

Raj, S.K., Srivastava, A., Chandra, G and 
Singh, B.P. 2002. Characterization of cucumber mosaic virus isolates infecting Gladiolus cultivars and comparative evaluation of serological and molecular methods for sensitive diagnosis. Curr Sci. 83: 1132-1137.

Raj, S.K., Srivastava, A., Chandra, G and Singh, B.P. 2002. Characterization of cucumber mosaic virus isolates infecting Gladiolus cultivars and comparative evaluation of serological and molecular methods for sensitive diagnosis. Curr Sci. 83: 1132-1137.

Revers, F., Le Gall, O., Candresse, T., Le Romancer, M., and Dunez, J. 1996. Frequent occurrence of recombinant potyvirus isolates. J Gen Virol. 77: 1953-1965.

Selvarajan, R., Gupta, M. Datta., and Misra, R.L. 1998. Screening of Gladiolus Cultivars against Bean Yellow Mosaic Virus. J Orn Horti. Vol - 1: Issue - 2 : $69-71$.

Shukla, D.D., Ward, C.W and Brunt, A.A. 1994. The Potyviridae. CABI, Wallingford. $528 \mathrm{pp}$

Singh, B.R., Dubey, V and Aminuddin. 2007. Inhibition of mosaic disease of Gladiolus caused by Bean yellow mosaic- and Cucumber mosaic viruses by virazole. Sci Hort. 114: 54-58.

Srivastava, K.M., Raizada, R.K and Singh, B.P. 1983. Bean yellow mosaic virus on Gladiolus psittacinus in India. Ind J Plant Pathol. 1: 83-88.

Vunsh, R., Rosner, A and Stein, A. 1991. Detection of bean yellow mosaic virus in gladioli corms by the polymerase chain reaction. Ann Appl Biol. 119: 289-294

Wylie, S.J and Jones, R.A. 2009. Role of recombination in the evolution of host specialization within bean yellow mosaic virus. Phytopathology. 99: 512-518.

Wylie, Stephen \& Coutts, B \& Jones, Michael \& Jones, R. 2008. Phylogenetic analysis of Bean yellow mosaic virus isolates from four continents: relationship between the seven groups found and their hosts and origins. Plant Dis. 92: 1596-1603.

Zettler, F.W and Abo El-Nil, M.M. 1977. Bean yellow mosaic virus infections on gladiolus in Florida. Plant Dis Rep. 61: 243-247.

\section{How to cite this article:}

Hemachandra Reddy, P., V. Venkataravanappa, P. Swarnalatha, K. V. Ashwathappa and Krishna Reddy, M. 2019. Characterization of Recombinant Bean Yellow Mosaic Virus belongs to Group-IV Infecting Gladiolus. Int.J.Curr.Microbiol.App.Sci. 8(09): 1644-1657. doi: https://doi.org/10.20546/ijcmas.2019.809.187 